\title{
The Last Unfinished Page of Genesis: Euclides da Cunha and the Amazon
}

Susanna B. Hecht - Professora do Departamento de Planejamento Urbano da Universidade da Califórnia, Los Angeles. Autora de inúmeros trabalhos sobre fronteiras e desenvolvimento.

\section{Resumo}

A preocupação de Euclides da Cunha com o meio ambiente, a economia política e a justiça social situa sua obra no âmbito daquilo que atualmente denomina-se ecologia política. Embora haja sempre o perigo de que a "escola" intelectual de hoje se torne a moda ultrapassada de ontem, a abordagem da Ecologia Política vem demonstrando grande longevidade. Nesse sentido, a obra amazônica de Euclides da Cunha é particularmente importante, devido à sua ênfase na análise ambiental, história social, relações sociais de produção, análise em larga escala e seus impactos sobre o meio ambiente, mostrando claramente ter sido o assunto de interesse do autor, um importante precursor da ecologia política. O presente trabalho examina a obra de Euclides da Cunha sobre a Amazônia a partir dessa perspectiva.

\section{Palavras-chave}

Ecologia política, Amazônia, Euclides da Cunha

\begin{abstract}
Euclides da Cunha concerns with environment, political economy, and social justice place him well within the ambit of what we toady call political ecology. While there is always a danger that today's intellectual "school" is yesterday's fad, the Political Ecology approach is showing great durability. Da Cunha's Amazon work is especially important in this regard with its emphasis on environmental analysis, social history, social relations of production, large scale analysis and their impacts on environment clearly show him as an important precursor in his interests to those of current political ecology. This article reviews his Amazon oeuvre in this light.
\end{abstract}

\section{Keywords}

Political ecology, Amazon, Euclides da Cunha. 


\section{EUCLIDES DA CUNHA: AN EARLY POLITICAL ECOLOGIST OF THE AMAZON? ${ }^{1}$}

Political ecology is increasingly seen as an approach and a series of concerns rather than a sub-discipline per se. It is generally viewed as a means of contextualizing resource use and its consequences within political economies that can range from the local to the international. Political ecology largely emerged from a broad focus on environmental degradation in developing countries, and typically concentrates on the contradictions of development and the "nature" of production in social terms (such as power relations, access regimes, divisions of labor, expropriation, distribution, displacements) and their biotic outcomes (e.g., deforestation, soil erosion, overgrazing, changes in land practices). A kindred focus embraces the dimensions of the "production" of nature through its social/environmental history, competing ideologies of nature and varying forms of representation, and how these ultimately translate into land use and policy. ${ }^{2}$ Social justice is also an explicit sub-theme in the analytics of the research area.

The explosion of this approach in geography and its close linkages to historical geography, ethnography, and other allied disciplines over the last thirty years, may have obscured what one might call "proto political ecologists" - thoughtful observers whose work is often unknown because it is not in English, or because the person lived before the lines of thought that now characterize political ecology had been baptized as such. Certainly, Mary Sommerville with her ardent emphasis on human impacts on environment and the effects of colonialism on native people, might qualify. ${ }^{3}$ Peter Kropotkin, the radical anarchist thinker, enchanted as $\mathrm{He}$ was by his Manchurian travels, might pass muster as a "proto political ecologist" given his optic on deconstruction of modes of science, his abiding respect for indigenous knowledge, his concern to break apart the underlying logics of production, and his view (echoed more than a century

\footnotetext{
${ }^{1}$ The quotations in the paper are the translations by the author of da Cunha's writings on the Amazon from my forthcoming volume, As Selvas: The Amazon Odyssey of Euclides da Cunha (Chicago: University of Chicago Press, in preparation). Da Cunha's citations in this text are to the publications in Portuguese. The volumes used here are Euclides da Cunha, Obra Completa (Rio de Janeiro: Nova Aguilar, 1966) and the compendium of his Amazon writings collected by Leandro Tocantins, O Paraíso Perdido: Ensaios, Estudos e Pronunciamentos sobre a Amazônia (Rio de Janeiro: José Olympio, 1978).

${ }^{2}$ See for example, Richard Peet and Michael Watts, eds., Liberation Ecology. Environment, Development, Social Movements (New York: Routledge, 1996).

${ }^{3}$ Mary F. Sommerville, Physical Geography (London: John Murray, 1848).
} 
later by James Scott) of state rationality as fundamentally disruptive to local resourcefulness and knowledge systems. ${ }^{4}$ These concerns, when coupled with the empathy for marginalized populations that inspired his philosophy, might indeed allow political ecologists to claim this Rebel prince. To a certain degree, one could insert the great statistician, peasant populist, and political activist, Alexander Chayanov, with his concerns for indigenous knowledge and the integrity of local economies into this group as well. ${ }^{5}$ Richard Grove's Green Imperialism provides an illuminating catalog of early colonial environmentalists, such as Poivre, Balfour and Forster. Certainly, a long list of early analysts could be developed who explored what have now become political-ecological themes, and this would be a useful exercise as political ecology enlarges its reach and consolidates itself through a broader arena of theory and practice. It would also, I suspect, increase the range of lineages that might be invoked as part of the intellectual precursors of political ecology. I believe an early "proto political ecologist" would be the great Brazilian writer and explorer, Euclides da Cunha, and especially his writings on the Amazon.

After a brief introduction discussing some major themes in Amazonian literature and the life of Euclides da Cunha (1866-1909), this article reviews da Cunha's thought through a discussion of current political ecology themes in Amazonian scholarship. A final section explores the limits and utility of applying modern concepts to writings that precede them by almost a century.

Amazonia in Political Ecology

Few locales are as evocative as the Amazon. Since its discovery it hás conjured up mirages of varying degrees of solidity—El Dorados for its conquerors and entrepreneurs; Tropical Utopias for proselytizing clergy and an assortment of other millenarian movements; it is the "last unfinished page of Genesis" (to quote da Cunha), or the Lost Eden for natural scientists; a Land Without Evil for its natives, the empty universe for its militaries and penal colonies; and, as Green Hell, a vast apparatus for crushing

\footnotetext{
${ }^{4}$ Peter Kropotkin, Fields, Factories and Workshops of Tomorrow (1899; reprint, London: Freedom Press, 1985) and The State: Its Historical Role (1902; reprint, London: Freedom Press, 1987); James C. Scott, Seeing Like A State (New Haven: Yale University Press, 1997).

${ }^{5}$ Alexander V. Chayanov, The Theory of the Peasant Economy (Madison: University of Wisconsin Press, 1986). The Last Unfinished Page of Genesis 66

${ }^{6}$ Richard Grove, Green Imperialism: Colonial Expansion, Tropical Island Edens, and the Origins of Environmentalism, 1600-1860 (Cambridge: Cambridge University Press, 1995).
} 
dreams for most of the shock troops of Amazonian occupation. Indeed, Slater argues in her compendium on Amazonia, Entangled Edens, that the place can only be understood through the web of its competing legends ${ }^{7}$ or as da Cunha remarked in his introduction to Alfredo Rangel's Inferno Verde, "Its space is like Milton's ... it hides from itself .... To see it, men must give up the idea of stripping off its veils." ${ }^{8}$ But even as Ama-zônia remains swathed in myths, it also is welded to a complex reality of massive land and social transformations, an enclosure movement of giddying speed and magnitude, and an explosion of infrastructure, massive urban and rural migrations, and the regular destruction of areas the size of Haiti. ${ }^{9}$ Transformations no less profound but less appreciated occurred in Amazonia many times in her history and most notably during the rubber boom.

The region has provided superior terrain for many types of political ecology studies, and several of its earliest efforts were produced there. ${ }^{10}$ Early Amazonian political ecology work concentrated on the impacts of land-use change at the tail end of Brazil's import substitution period as conceived and largely implemented under authoritarian rule, but Amazônia has always provided a context for the materialization of complex ideas and ambitions. ${ }^{11}$

${ }^{7}$ Candace Slater, Entangled Edens: Visions of the Amazon (Berkeley: University of California Press, 2001).

8 "Inferno Verde," or "Green Hell," was one of the early literary "novelizations" or vignettes of forest conditions and enjoyed great interest at the time of its first publication in 1907; da Cunha, "Inferno Verde," O Paraíso Perdido, 201. As Cleary has pointed out elsewhere, the "dystopic" version of the Amazon stood in contrast to the generally positive view of the region. Meanwhile, the close relation between Rangel and da Cunha suggests that they shared similar political and humanist concerns. David Cleary, "Science and the Representation of Nature in Amazonia: From la Condamine, da Cunha to Anna Roosevelt," in Ilton Vieira, José Cardoso da Silva, David Oren, and Maria d'Incao, eds., Diversidade Biolôgica e Cultural da Amazônia (Belém: Museu Goeldi, 2001).

${ }^{9}$ Richard Houghton, David Skole, Carlos Nobre, James Hackler, and Kevin Laurence, "Annual Fluxes of Carbon from Deforestation and Regrowth in the Brazilian Amazon," Nature 403 (2000): 301-4.

${ }^{10}$ See, for example, Marianne Schmink and Charles Wood, "Political Ecology of the Amazon," in Peter Little, M.H. Horowitz, and A.E. Nyerges, eds., Lands at Risk in the Third World (Boulder: Westview Press, 1987): 38-57; Susanna Hecht, "Environment, Development and Politics: Capital Accumulation and the Livestock Sector in Eastern Amazonia," World Development 13:6 (1985): 663-84.

${ }^{11}$ There are several volumes that deal with this question. See Susanna Hecht and Alexander Cockburn, Fate of the Forest (London: Verso, 1989); Marianne Schmink and Charles Wood, Contested Frontiers In Amazonia (New York: Columbia University Press, 1992); Hugh Raffles, In Amazonia: A Natural History (Princeton: Princeton University Press, 2002); Stephen Nugent, Amazon Caboclo Society (London: Berg, 1992); Susanna Hecht, "Solutions or Drivers: Dynamics of Deforestation in Bolivia," Development and Change (in press). 
While there are several reviews of the region's modern political ecology, the ideologies and history of its occupation have become a central part of its current research agenda. ${ }^{12} \mathrm{~A}$ few general political ecology and historical geography topics, while not unique to the Amazon, have been especially important in Amazonian scholarship and da Cunha's oeuvre. These include questions of the "natures of nature" and take on three significant themes - the "construction of nature" as it reflects myths, imaginings, and/or received ideas about the place; the "nature of nature" or the scientific dimensions and controversies attending the understanding of the region; and finally, the intimate interaction of nature and people. Crudely, we might think of these as myths, sciences, and human realities in the Amazon context. ${ }^{13}$ These approaches create frameworks that are complemented by others that focus more explicitly on production-the hidden histories of landscapes and economies, and comparative forms of regional occupation.

\section{THE NATURE OF NATURE}

The Mythic Amazon

Perhaps one of the most powerful themes in the political ecology of conservation, colonial expropriation and modern development is the Idea of the empty landscape, the tropical tabula rasa. ${ }^{14}$ The Empty

${ }^{12}$ David Cleary, "Towards an Environmental History of the Amazon: From Prehistory to the Nineteenth Century," Latin American Research Review 36:2 (2001): 65-96; William M. Denevan, Cultivated Landscapes of Native Amazonia and the Andes (Oxford: Oxford University Press, 2001); James Peterson, Eduardo Neves, and Michael Heckenberger, "Terra Preta: Gift from the Past," in Colin McEwen, Christina Barreto, and Eduardo Neves, eds., Unknown Amazon: Culture in the Nature of Ancient Brazil (London: British Museum Press, 2001): 86-107; Hugh Raffles and Antoinette M.G.A. WinklerPrins, "Further Reflections on Amazonian Environmental History: Transformations of Rivers and Streams," Latin American Research Review 38:3 (2003): 165-87; Hecht and Cockburn, Fate of the Forest.

${ }^{13}$ Each of these terms is loaded, but the terrain is addressed in several volumes: Candace Slater, Entangled Edens; Hugh Raffles, In Amazonia; Hecht and Cockburn, Fate of the Forest; Nancy Stepan, Picturing the Tropics (Ithaca, NY: Cornell University Press, 2001); Nugent, Caboclo Culture; Neil Whitehead, History and Historicities in Amazonia (Lincoln, NE: University of Nebraska Press, 2003).

14 The importance of this idea has been reviewed in Roderick P. Neumann, Imposing Wilderness: Struggles over Livelihood and Nature Preservation in Africa (Berkeley: University of Califórnia Press, 1998); see also Mary Louise Pratt, Imperial Eyes: Travel Writing and Transculturation (New York: Routledge, 1992); Michael Dove, "The Practical Reason of Weeds in Indonesia," Human Ecology 14:2 (1986): 163-90. 
Amazon - as Lost Eden or Lost World - has had a durable presence in the iconography of Amazônia and one with important implications. A tabula rasa is a world without history, a vacant template, a place that is immanent, undefined, and available for the transformative civilizing mission that takes the region from inchoate nature into that of "imposing wilderness" for conservationists, natural resources for developers, and from "space" to political "place" for nation-states. This blank slate permits the revision of the past in order to define its nature and future in particular ways - thus the TransAmazon highway becomes the popular colonization slogan "A Land without People for a People without Land," regardless of the resident traditional populations whose terrains were obliterated by the new development maps.

The idea of the empty Amazon also shaped the view of the region as a cornucopia of natural resources for guiltless plunder and biopiracy. ${ }^{15}$ As da Cunha notes, the wretched plight of quinine bark hunters stranded in the tropical foothills of the Andes were a result of the theft and sale of Cinchona seeds to Dutch colonialists by the entrepreneurial adventurer George Ledger. This ultimately resulted in plantations in Java that destroyed a significant part of the Peruvian economy while facilitating European tropical colonialism. ${ }^{16}$ This, of course, presages the piracy of rubber seeds that later ravaged Amazonia, ${ }^{17}$ an outcome that da Cunha did not live to see. Plunder, and its political economy, remains a Constant theme in his work, as it has for most modern Amazon scholars.

Counternarratives exist to the empty Amazon, but they are of quite recent vintage. Though more closely allied with environmental history and historical demography than political ecology per se, the current outpouring of research on large-scale landscape modification is emblematic of contemporary efforts to recast Amazonia's past as one of populous, complex engineering societies rather than empty "counterfeit

\footnotetext{
${ }^{15}$ The degree to which Amazonia's resources were ravaged is described in David G. Sweet, "A Rich Realm of Nature Destroyed: The Middle Amazon Valley, 1640-1750," Ph.D. diss., University of Wisconsin, Madison, 1974; Stephen Bunker, Underdeveloping the Amazon (Chicago: University of Chicago Press, 1985).

${ }^{16}$ Da Cunha, "Os Peruanos," O Paraíso Perdido. See also, Anton Hogstad, ed., Proceedings of the Three Hundredth Anniversary of the First Recognized Use of Cinchona (St. Louis, MO: Missouri Botanical Garden: 1931); Richard Spruce, Notes of a Botanist on the Amazon and Andes (London: MacMillan, 1908); Flammina Rocco, The Miraculous Fever Tree (London: Harper-Collins, 2003).

${ }^{17}$ Warren Dean, Brazil and the Struggle for Rubber (Berkeley: University of Califórnia Press, 1987).
} 
paradises."18 Other research efforts revise the idea of "empty Amazonia" by focusing on the smaller scale "anthropogenic Amazon," and privileging the incremental effects human agency exerts in constructing and managing a broad array of environments that cumulatively have transformed the region into both artifact and habitat. ${ }^{19}$

The writings of da Cunha also re-inhabit the tropics with its native people, as well as successive forays of clerics, bureaucrats, scientists, adventurers, and its humble Brazilian northeastern colonists-his "brown titans" who claimed the Amazon through their dogged efforts. His populated Amazon diverges profoundly from the image on offer by outside colonialists of the time (both Brazilian and foreign) who envisioned it as a bounteous immensity conveniently void of significant residents, a place especially apt for European and American immigration because the local interracial stock was too degraded or relaxed to take on the noble task of regional occupation. His Amazon, on the other hand, is never empty, and swarming with mythologies, histories, and evolving societies.

\section{The Scientific Amazon}

Scientific debates and narratives increasingly form part of the body of research included within political-ecological studies. ${ }^{20}$ The early twentieth century was awash in questions about the origins, purposes, and processes of the natural world as increasingly rigorous information flowed

\footnotetext{
${ }^{18}$ Counterfeit Paradise refers to Anthropologist Betty Meggers' classic text Amazonia: Man and Culture in a Counterfeit Paradise (Chicago: Aldine, 1971), where she argued that the environment could only support a very limited population and inhibited cultural evolution. Some examples of the counter position are found in Denevan, Cultivated Landscapes of Native Amazônia and the Andes; Peterson, Neves, and Heckenberger, "Terra Preta: Gift from the Past;" Johannes Hecht 67 Lehmann, Dirse C. Kern, and William I. Wood, eds., Amazonian Dark Earths: Origins, Property, Management (Dordrecht, Netherlands: Kluwer, 2004); Bruno Glaser and William Wood, Amazon Dark Earths: Explorations in Time and Space. (Heidelberg, Germany: Springer-Verlag, 2004); William Balée, ed., Advances in Historical Ecology (New York: Columbia University Press, 1998); Clark L. Erickson, "An Artificial Landscape-Scale Fishery in the Bolivian Amazon." Nature 408:6809 (2000): 190-3; M. Heckenberger, J. Petersen, and E. Neves, "Village Size and Permanence in Amazônia," Latin American Antiquity 10 (1999): 353-76.

${ }^{19}$ These works include Hugh Raffles, In Amazonia; Christine Padoch, Marcio Ayers, Miguel Pionedo-Vasquez, Andrew Henderson, eds., Varzea (New York: University of Columbia Press, 1999); Darrell Posey, Kayapo Ethnoecology (New York: Routledge, 2002); Raffles and WinklerPrins, "Further reflections on Amazonian Environmental History."

${ }^{20}$ See for example Neumann's Imposing Wilderness; Melissa Leach and James Fairchild, "False Forest History, Complicit Social Analysis: Rethinking Some West African Environmental Narratives," World Development 23:6 (1995): 1023-35; Arturo Escobar, "Whose Knowledge, Whose Nature? Biodiversity, Conservation, and the Political Ecology of Social Movements," Journal of Political Ecology 5 (1998): 53-82.
} 
from the tropics to the scientific metropoles of Europe. These, not surprisingly, sparked profound disputes, such as those between creationism and Darwinism, between catastrophist and gradualist theories of life and landscape, and what these theories might mean about the nature and meaning of race. ${ }^{21}$ The nature of Amazonia as Forest Primeval, some kind of static "Ur-Wald," that has been inert and intact from time immemorial, versus a dynamic realm of evolution, resilience, and change, is a significant theme among tropical ecologists and was compelling for da Cunha. ${ }^{22}$

Modern political ecology focuses much more on the impact of people on environment, although there is an emerging trend by writers such as Karl Zimmerer and Thomas Bassett, suggesting that environments have an effect on people and societies, not in the ways understood in environmental determinism, but rather as mediated by its symbolic and cultural meanings, as well as resource possibilities. ${ }^{23}$

The effect of tropical nature on people was a question of both theoretical interest as a sub-area of environmental determinism and social Darwinism, but also of pressing practical concern for colonial enterprise around the world. Both as a scientist and as an "internal" colonialist, da Cunha had a decidedly modern perspective on these questions, and one deeply situated in and informed by secular theories of Darwin, but in a manner at odds with his time and much of his own previous work.

The Production of Landscape

Hidden social histories are an important concern in political ecology, and increasingly so in current Amazonian scholarship. ${ }^{24}$ The recovery of

\footnotetext{
${ }^{21}$ Dain Borges, "Puffy, Slothful, Ugly and Inert: Degeneration in Brazilian Social Thought," Journal of Latin American Studies 25:2 (1993) 235-56; Mike Hawkins, Social Darwinism in European and American Thought 1860-1945 (Cambridge: Cambridge University Press, 1997); Thomas Glick, Miguel Puig-Samper, Rosanna Cruz, eds., The Reception of Darwinism in the Iberian World (Dordrecht, The Netherlands: Kluwer, 2001); Nancy Stepan, The Hour of Eugenics (Ithaca, NY: Cornell University Press, 1991).

${ }^{22}$ See for example Daniel Botkin, Discordant Harmonies (New York: Oxford University Press, 1990); Karl S. Zimmerer, "Human Geography and the New Ecology: the Prospect and Promise of Integration," Annals of the Association of American Geographers 84:1 (1994): 108-25.

${ }^{23}$ See Karl S. Zimmerer and Thomas Bassett, Political Ecology: An Integrative Approach to Geography and Environment-Development Studies (New York: Guilford, 2003); Philippe Descola, In the Society of Nature (Cambridge: Cambridge University Press, 1999).

${ }^{24}$ This area is becoming especially rich. See, for example, Peter Redfield, Space in the Tropics: From Convicts to Rockets in French Guiana (Berkeley: University of California Press, 2000); Michael Brown, The War of Shadows: the Struggle for Utopia in the Western Amazon (Berkeley: University of California Press, 1991); Christina Wolff Mulhers da Floresta (São Paulo: Hucitec, 1999).
} 
indigenous history and land uses, the importance of small-scale agency and traditional peoples, as well as invisible yet powerful actors such as corporations in the creation of localities, has produced an extensive literature on the forces that shape Amazon landscapes. ${ }^{25}$ One of da Cunha's noteworthy contributions is his attention to the convulsive social changes in the region in the midst of one its most dramatic economic booms, especially when set against the relentlessly biological descriptions of the Amazon by outside observers. The waves of enterprise and colonization flow and ebb in da Cunha's Amazon like the floods of the region's rivers. He especially emphasizes the mixed-blood peasants (caboclos) who forged the routes and landscapes that shaped the region's economy and history, and often guided the famous European explorers.

Finally, the impacts and political economies of forms of development in both social and environmental terms have been a central part of Amazonian scholarship in political ecology. This theme underlies much of da Cunha's Amazonian commentary. He was actively trying both to understand and to shape the region, and his deep sensitivity to social injustice infuses his passionate descriptions and his own imaginings of a different kind of future for the region.

These elements of political ecology and of da Cunha's contributions need to be anchored to his place and time. While to do so in a complete way is well beyond the scope of this article, it is useful to understand the circumstances that propelled him into the region, and the elements of his own biography that informed and inspired his understanding of the Amazon and its people.

The Scramble for Amazonia

While little noted in Europe, involved as it was with its own partition of the African continent, many South American countries were engaged in the "Scramble for the Amazon," during the nineteenth century when elastic gums, including the vast Acrean rubber forests, were of unparalleled importance. A flotilla of explorers, ranging from princes to commercial collectors, had passed through Amazonia on royal expeditions or on financial collecting propositions during the eighteenth and nineteenth centuries, and were largely concerned with reports of oddities, novelties,

${ }^{25}$ Schmink and Wood, Contested Frontiers; Hecht and Cockburn, Fate of the Forest; Padoch et al., Varzea; Raffles, In Amazonia. 
and agricultural resource reviews - a sort of combination of spying reports, development recommendations, and adventure tales-and to document such curiosities that might be useful later for the lecture circuit or biopiracy. ${ }^{26}$ Famous naturalists had plied the enormous rivers with great tales of biology and/or uplifting plans for its future for more than a century. Some travelers and explorers like the U.S. military men William Lewis Herndon and Matthew Fontaine Maury (both on U.S. "resource" reconnaissance), and Louis Agassiz (founder of Harvard's Natural History Museum and ardent defender of creationism and theories of racial superiority) viewed the region as ideal for industrious American colonization including that of Confederate slave holders and barely noted the social relations, often more egregious than slavery, unfolding behind the forests' green veil. ${ }^{27}$ Later, others, like H. Arnous de Riviere, saw the Amazon as a useful haven for freed American slaves, a kind of New World Liberia. $^{28}$

Da Cunha was writing almost a hundred years ago, at the height of the rubber boom, when the industrial revolution was just beginning to consolidate itself into vertically integrated production and finance systems for one of the world's most coveted commodities. Most travelers saw the outposts they passed through as static entities, and rarely as the outcome of a complex and disturbing history. Few were even aware of the deeply dislocating economic and political waves that flowed over the region for hundreds of years, or even that the region had been convulsed by a major regional civil war that had devastated the population in the 1830s, the Cabanagem revolt. ${ }^{29}$ These travelers usually paid little mind to the immense economic apparatus that was literally all around them. It was seen, in any case, as a matter of little importance compared to documenting wild paradise or paving the path to more earthly imperial rewards.

\footnotetext{
${ }^{26}$ The much lauded Richard Spruce (see endnote 16) sent seeds of cinchona to Kew Gardens that were then planted in India. Their level of quinine was very low however. The real biopirate in this story is George Ledger; see Rocco, The Miraculous Fever Tree. The famed explorer Charles Marie de la Condamine was also an important agent of colonial biopiracy, see Charles Marie de la Condamine, Voyage sur l'A mazone (1778; reprint, Paris: Maspero, 1981).

${ }^{27}$ William Herndon, Explorations of the Valley of the Amazon (1854; reprint, New York: McGrawHill, 1952); Louis and Mrs. Agassiz, A Journey in Brazil (New York: Houghton Mifflin, 1898); Frank Maury, Valley of the Amazon (Washington, DC: Frank Taylor, 1853).

${ }^{28} \mathrm{H}$. Arnous de Riviere, "Explorations in the Rubber Districts of Bolivia," Journal of the American Geographical Society of New York 32:5 (1900): 432-40.

${ }^{29}$ Hecht and Cockburn, Fate of the Forest; David Cleary, "Lost Altogether to the Civilized World: Race and Cabanagem in Northern Brazil 1780-1850," Comparative Studies in Society and History 40 (1998): 109-34; Pasquale di Paulo, Cabanagem: A Revolução Popular da Amazônia (Belém: CEJUP, 1985).
} 
Yet the region was deeply contested. Expeditions from Peru, Bolivia, Colombia, and Ecuador sought to claim the Amazon. The Bolivian syndicate, an American-Bolivian cartel, was prepared to take over much of Acre, and control one of the world's most valuable resources. Countless border skirmishes occurred in the rich rubber forests, as country after country - including, covertly, the U.S.—vied for sovereignty over the terrain occupied by one of the world's most vital commodities and a region with still unknown, yet vast resources. After a guerilla war in which rubber tappers triumphed over General Pando's Bolivian army, (the Proxy battalion for the U.S.-financed syndicate), the boundaries of the Western Amazon were redrawn in the 1903 Treaty of Petrópolis, which recast the frontiers of Bolivia, Peru, and Brazil, all of whom had claimed the area. ${ }^{30}$ Surveying parts of the newly negotiated frontier was necessary and would be carried out by a joint commission of Peruvians and Brazilians.

It was as a member of this survey team that the highly "coastal" Euclides da Cunha was thrust, by chance and destiny, into Amazonia. I will return to the political-ecological and historical-geographical content of Euclides' writings, but elements of his own history and his analytic approach are useful in understanding his intellectual trajectory, and why we might think of him as a "proto" political ecologist.

\section{Euclides Who?}

The name Euclides Da Cunha does not trip from every lip in the Anglophone world of resource studies. He resides mostly in a quite different world of literature. Euclides da Cunha is not only regarded as one of the greatest writers Brazil has produced, but also one of the most luminous stylists to ever have written in Portuguese. His work is known in English largely through Os Sertões (Rebellion in the Backlands), published in 1902.

This famous work chronicles the suppression of the Canudos uprising of 1896-97 — a millenarian revolt led by the charismatic leader Antonio Conselheiro, whose followers were impoverished laborers of the harsh Brazilian outback, and a rag-tag lot of bandits and cowboys. It is one of the most extraordinary accounts of a military campaign (and guerrilla warfare) not only because of the brilliance of the writing, but

\footnotetext{
${ }^{30}$ This was the area encompassing an oblique line from the Madeira River at ten degrees, twenty minutes south to the source of the Javari River. It involved an area of some 73,000 square miles.
} 
because the voice gradually becomes sympathetic to the doomed rebels. Resisting the incorporation of the region into the Brazilian Republic, the backwoodsmen held off a siege of 6,000 troops. In three months, Brazil's well-armed militia advanced less than 100 meters. The siege eventually took its toll and the republican army triumphed, but only after house-tohouse combat extraordinary in its blood-drenched brutality on both sides. The visual portrayal of the physical milieu in which both guerrilla and conventional battles unfold is the Brazilian agreste, or thorn scrub forest, a spare and violent landscape, which infuses the nature of the military engagement itself, since the battle is as much for survival in the sere terrain as triumph over other troops. The volume reveals the nature of the new "revolutionary" secular state when confronted with a messianic movement composed of the most powerless elements of Brazilian societydetribalized Indians and abandoned ex-slaves - in a ringing indictment. He intended his "O Paraiso Perdido" to be a companion volume to Os Sertões and in many ways the fragments he wrote on the Amazon contain many structural elements that parallel his novel-the landscape description, the social relations, and the regional history.

His Amazonian writing extends the saga of the ravaged Northeasterners to their next economic and geographic phase. After failed resistance, the last gasp of the sugar boom, the end of slavery, a collapsed economy, and among the harshest of El Niño related droughts, came migration to the Amazon. Dazzling natural descriptions, and incisive social commentary characterize this part of his legacy, and like his "Iliad" (Os Sertôes), his own "Odyssey" (O Paraíso Perdido) explodes the national "foundational fictions" of the young Brazilian Republic by exploring the environment, economy, and empire of the Brazilian Amazon in its complex geophysical and biotic majesty, its emergent societies, and its brutal exploitation of man and nature. His Amazon material, by his own assessment, was to be his masterwork. Amazonia deeply shaped his political and intellectual positions and, of course, also drove him mad.

Da Cunha was trained as a humanist and scientist; he was an ardent student of revolutionary thought, a disciple of the French political and social theorist Benjamin Constant, and a protégé of Constant's charismatic Brazilian namesake, Benjamin Constant de Botalhão de Margalhães. ${ }^{31}$ The

\footnotetext{
${ }^{31}$ Benjamin Constant is hardly known anymore, but his writings on liberal political and democratic philosophy were extremely influential in the nineteenth century; see Tzvetan Todorov, Benjamin Constant: La Passion Democratique (Paris: Hachette, 1997); Stephen Holmes, Benjamin Constant and the Making of Modern Liberalism (New Haven, Yale University Press: 1997).
} 
Brazilian Benjamin Constant was an eminent abolitionist, and the architect of the young Republic. ${ }^{32}$ As a consequence of these influences, da Cunha's writings demonstrate an unusual sensitivity to both the natural world and to men's positioning within it. Indeed, the violence of man to nature and man to man become metaphors of each other. He was disdainful of what he called "hedonistic" writing, and, like the French authors and social activists Emile Zola and Victor Hugo, whom he admired, he felt that all writing had to produce an effect in the world. ${ }^{33}$ Thus, he was from the beginning an advocacy and political writer, clearly committed in his art and science to social transformation.

Da Cunha, the mestizo grandchild of a Portuguese slaver was part of the extremely tenuous middle class that was trained in the military as one of the very few means of social mobility within the rigid plutocracy of Brazil's Belle Epoque. He came of age in a period of tremendous intellectual and political turmoil. He grew up when fundamental questions about the institutions and structure of Brazilian society were subjects of intense debate-the future of slavery, forms of government, and democracy. Enormous social and political dislocations occurred as transformations in the structure and location of Brazil's economic dynamos shifted from northeastern sugarcane to southern coffee and Amazonian rubber. The continuous uprisings throughout Brazil that attended these changes were the topics of the day. In this world of upheaval, he had a central position as na actor in each of its key moments, from the insurrection that began the pathetic doom of Emperor Don Pedro, to the consolidation of the Brazilian Republic through the labors of its most brilliant diplomat, the Baron of Rio Branco. As a journalist and writer, he helped create the ideological and intellectual milieu in which political action would unfold. As an uncannily brave soldier, surveyor, and explorer, he was himself an actor in the history his ideas shaped. Strongly influenced by European thinkers and writers- the founder of sociology, Auguste Comte, the political novelists Zola and Victor Hugo, the geographer Friederich Ratzel—he was also profoundly affected by

\footnotetext{
${ }^{32}$ Benjamin Constant Botalhao de Margalhães was a charismatic teacher at the military academy of Praia Vermelho and trained the insurgents who founded the First Republic. He was extremely important in the abolition movements as a result of his experience in the War of Paraguay, see Ivan Lins, História do Positivismo No Brasil (São Paulo: Companhia Editora Nacional, 1967). The Last Unfinished Page of Genesis 68.

${ }^{33}$ This was in part a response to the movement of "art for art's sake" that infused romantic writing and poetry and was also associated with Oscar Wilde.
} 
Comtean positivism and Social Darwinism, the secular development ideologies of the age.

He left the army in 1896, became a civil engineer for the state of São Paulo, and continued his journalistic writing. It was from this post that He left with the São Paulo Battalion to the barrens almost 1,500 miles to the north to cover the Canudos uprising, which at the time was being billed as a monarchist rebellion that had somehow defeated the new Republic's most brilliant military tacticians. The final account produced his epic Os Sertões (1902). This volume was a critical and popular success, which resulted in his connections with Brazil's literati (such as novelist Machado de Assis), and drew the attention of the Baron of Rio Branco. ${ }^{34}$ The Baron, who had resided for decades abroad as Ambassador to the U.S. as well as France, was instrumental in advancing Brazil's claims to the vast, unmarked territories whose contours had been formerly traced by the Treaty of Tordesillas in 1496 but bickered over ever since. During the Baron's tenure, Brazil increased its national territory by an area the size of France. As a master geopolitician and man of letters, Rio Branco was attracted to da Cunha through his early writings on Brazil's geopolitics, and of course his famous book. In addition, his military training and survey skills suited him well for the task of leading the joint survey team to the headwaters of the Purus River. This area was extremely remote, and had only been formally explored by the British explorer William Chandless in the 1860s. Still the scene of skirmishes between natives and between nationalities, the commission was charged with the task of arriving at the headwaters of the three great rivers - the Purus, the Ucayali, and the Madre de Dios.

Da Cunha was attracted to the task in part because of his interest in the Acrean rebellion, which had, through guerilla warfare, defeated Bolivian troops, and proclaimed itself for a time, the independent Republic of Acre. The ideals of the "Republic of Poets," as the Acrean independence movement called itself, were rooted in those of the French revolution, and deeply appealed to his political sensibilities.

His expedition was preceded by a lengthy stay in Manaus with many bureaucratic delays, during which he educated himself on Amazonian history and science in the local archives, and in the extensive library of his

\footnotetext{
${ }^{34}$ Machado de Assis was one of Brazil's most famous writers and continues to be thought of as na early modernist. Highly ironic in style, he is best known for the works Philosopher or Dog?, Don Casmurro, and Epitaph of a Small Winner.
} 
friend Rangel's comfortable bungalow called Vila Glicinia. Here he began to develop his highly informed and original interpretation of the region's sociology and ecology. He wrote about the lost history of Amazonia, which in fact would probably have disappeared without his brilliant fragments. This immersion in the region's "grey literature" as well as the science of his day infused his Amazonian writings with a sensibility to historical biogeography, and allowed him to address themes that would embrace what today constitute some of the themes of political ecology as well as those of "subaltern" or postcolonial analysis.

The trip itself was fraught with disaster-shipwrecks, fevers, the endless sneering on the part of the Peruvians, equipment failures, and starvation. In spite of constant misadventure that bordered somewhere between the Jobean and the slapstick, da Cunha did arrive finally at the headwaters before his Peruvian colleagues.

He enjoyed many accolades-he was elected to the Historical Institute and the Brazilian Academy (rather like the Academie Française), worked as part of Baron Rio Branco's cabinet, and was appointed to the Chair of Logic at the Pedro II Institute. But he was enervated by life at court, exhausted from his scholarly work, and tormented by the public adultery of his wife. He dreamed of joining his old school friend, Rondon (who became the founder of Brazil's Indian Protection agency), on a new Amazonian foray into the vast unknown of Mato Grosso and points north, as one means of fleeing a personal and professional situation that had become ever more an affliction. ${ }^{35}$ He was generally impoverished, deeply humiliated by his wife's infidelity, and felt that the revolution and the Republic had betrayed its ideals. This was possibly the impulse behind his founding of Brazil's first socialist party with his patron, Francisco de Escobar. ${ }^{36} \mathrm{He}$, however, was destined neither to complete his companion volume nor to re-engage Amazonia (and its indigenous question through Rondon), as in 1909 he was killed in a duel with his wife's young lover.

\footnotetext{
${ }^{35}$ Cândido Rondon was the founder of Brazil's Indian protection agency, and his eight-year expedition (begun in 1907) to establish a telegraph line through Mato Grosso up to Cuiabá was committed to peaceful contact with Brazil's native populations, and made many "first" contacts with local tribes. Claude Lévi-Strauss followed much of Rondon's trek in his celebrated Tristes Tropiques (1955; reprint, London: Penguin, 1992).

${ }^{36}$ Francisco Escobar, who founded the first Socialist Party in Brazil, was da Cunha's frequent correspondent and patron while he wrote Os Sertôes.
} 


\title{
DA CUNHA'S AMAZON AND THE POLITICAL ECOLOGY APPROACH
}

\section{Episteme and Method}

In an Amazon that was largely viewed through the lens of foreign science and ambition, da Cunha, as a native intellectual, provides an optic on the region, on the scientific debates it engendered, on colonialism and on Amazonian geography and history that was invisible to virtually all other observers. His sources included the documents of the early government and ecclesiastic papers, bureaucratic accounts of unglamorous expeditions whose findings informed the activities of local administrators, and the chronicles of the great eighteenth- and nineteenth-century naturalists and tropical scientists. This complemented his own discovery of the Amazon as he trekked up some of its most isolated tributaries, observed and measured the region, and took in its oral history. This training and experience had three effects on his approach-an appreciation of the complexity of ecosystem types, the power of the scientific analysis and metaphors when integrated with the social sciences, and finally the importance of native "voice" and knowledge. ${ }^{37}$ First, he discusses the view that the Amazon immensity could not be understood by even brilliant scholars Who stood only at its threshold:

\begin{abstract}
Most of the great naturalists never left the course of the great river... [Henry Walter Bates] lived in Amazonia for more than a decade making memorable discoveries that would support his nascent theory of evolution. ${ }^{38}$ During that period of forced suffering and affliction, he didn't leave the narrow strip of litoral
\end{abstract}

\footnotetext{
${ }^{37}$ Approaches in political ecology are reviewed by Karl Offen in this volume, but also see Raymond Bryant, "Power, Knowledge and Political Ecology in the Third World," Progress in Human Geography 22:1 (1998): 79-94; Karl S. Zimmerer and Thomas Bassett, "Approaching Political Ecology: Society, Nature, and Scale in Human Environment Studies" in Political Ecology: $\mathrm{Na}$ Integrative Approach to Geography and Environment-Development Studies, 1-25.

${ }^{38}$ While Alfred Wallace is usually given credit for simultaneously developing the theory of evolution with Charles Darwin, there are two things to keep in mind. First, Wallace and Henry Bates traveled for several years together on the lower Amazon, but separated after a stay in Manaus - Wallace to ascend the Rio Negro and Bates to continue up the main channel to Ega or what is now known as Tefe. Certainly they shared their thoughts over these many years. On his return from Amazonia, Bates corresponded with Darwin about "Batesian mimicry," which is a rather dramatic outcome of natural selection, and it is to this that da Cunha refers. The definitive sixth edition of Charles Darwin, Origin of Species (New York: A.J. Burt, 1890), uses this form of mimicry as a persuasive resolution to the puzzle of selection: Raffles deals with this issue at greater length, see his In Amazonia, 118-9.
} 
that runs between Belém and Tefe. Yet from there he stunned institutions in Europe, gained the admiration and enthusiasm of Charles Darwin, and reworked many chapters of natural history. At the end of this fertile enterprise, he could guarantee that he had not depleted even the slender band where he sheltered. He never saw Amazonia. But from his perch, he saw more than his predecessors did. ${ }^{39}$

Next, he posits, a type of "scientific magical realism," arguing that science and sociology needed to be integrated in order to understand the processes he observed. Da Cunha was a committed positivist who often felt that the scientific lexicon produced more effective imagery and accurate metaphors than literary prose. Writing about his friend Rangel's memoirs and stories of the Amazon, Inferno Verde, he states:

Rangel has the perfect appearance of a poet but is too exuberant for the discipline of meter and rhyme. He is an engineer skilled in the most objective and calculating technical processes. The surprising reality came to his eyes through the lens of a theodolite. He organizes his fantastic scenarios through the coordinates of triangulations. The dreamer aligned his way on compass coordinates. His most moving insights were corrected with the azimuth .... He inverted, without wishing to, the vulgar canons of art. His is a temperament seen through a new nature. He altered nothing. He merely copied and described. It is from this that emerged his surprises .... Because what is fantastic and incomprehensible is not the author, but Amazonia. ${ }^{40}$

It is his interest in careful recording that made both his novel and his Amazon reportage so compelling.

Finally, as a Brazilian, a nationalist, and an experienced analyst of Brazil's "outback," he felt that Brazil should rely more on its native understanding rather than filtering knowledge and paradigms through external ideas and languages, especially given the craze for all things foreign during Brazil's Belle Epoque. ${ }^{41}$

\footnotetext{
${ }^{39}$ Da Cunha, "Inferno Verde," O Paraíso Perdido, 201.

${ }^{40} \mathrm{Da}$ Cunha, "Inferno Verde," O Paraíso Perdido, 202.

${ }^{41}$ Jeffrey Needell, A Tropical Belle Epoque: Elite Culture and Society in Turn of the Century Rio de Janeiro (Cambridge: Cambridge University Press, 1987).
} 
Our critical conceptions are so unstable that even our current sentences are transitory. Before launching into works of this kind, (like the Green Hell) whose peculiarity comes from a profound originality, it behooves us not to forget the false and uncharacteristic in our mental structure, where so dominate the reagents improper to the genius of our race. We think too much in French, in German, or even in formal Portuguese. We live in a spiritual colony almost a century after political autonomy. From the construction of phrases to the organization of ideas, we too much respect the prejudices of exotic cultures that impress us, and form in us a singular state of consciousness, blind to the real depictions of our lives, such that our own character is lost to us, papered over by other attributes that diminish and discount the convergences of our origins .... A kind of psychic mimicry has been instituted and in this cowardice we camouflage ourselves in the external similarities to the people who both intimidate and enchant us. To the degree that we explore our own reality we must overcome the preconception that we must be as little Brazilian as possible. And thus we eruditely render (our experience) into formal Portuguese, forgetting that our greatest pride should consist in our own idiomatic language confounding their translations .... In any case, it is time we emancipated ourselves. ${ }^{42}$

Of the legions of European and American emissaries who flocked to Amazonia on their scientific expeditions, da Cunha was one of the very few to see past the biota or colonial schemas into the social history that was unfolding and shaping the forests. His intellectual approach and personal history permitted him to view both the society and nature that were evolving in Amazonia in an integrative way. These underlying epistemes were to infuse his analysis of Amazonia. The next section reprises the earlier themes of Amazonian political ecology, and da Cunha's writing on these topics.

\section{DA CUNHA'S AMAZONIA}

\section{Constructed Amazons: The Empty World}

The idea of an empty Amazon, a realm of some kind of natural primordial past, has maintained a perennial hold on the conceptualization of the place. Throughout various sections of his Amazonian works, da

${ }^{42}$ Da Cunha, "Inferno Verde," O Paraíso Perdido, 207. 
Cunha analyses how the myth of emptiness obscured the density and richness of native occupation, and how that idea shaped the understanding of Amazonia. It is emblematic that at one of the most remote outposts of the Amazon, in the varadouro (or passage) connecting the beginning of the enormous watersheds of the Purus, the Madre de Dios, and Ucayali rivers, da Cunha and his diminished and starving survey team encountered the detritus of broken knives, leftover containers, and derelict shelters of this obviously well-used corridor. ${ }^{43} \mathrm{Da}$ Cunha points out the convenience of the "empty Amazon" for validating observers" preconceived ideas and how important these became in establishing "truths" about the region, how "blankness" served to obliterate or ignore indigenous or popular history, and how external agendas diminished the ability of the observers to see what was around them. It was not an empty place for him, but $\mathrm{He}$ notes how empty it seemed to some, because their specific purposes blinded them to the region's reality. Take for example this comment on the Purus River:

[The Purus] appears completely foreign to our history, and is often resumed in the phrase of Padre Joao Daniel in his imaginative Tesouro Descoberto [Discovered Treasure] which sums up the knowledge of the old chroniclers - "Between the Javari and the Madeira - a distance greater than 200 leagues, is no population whether of whites, Indians, or Missions...." The emptiness is informed less by real conditions than by the unfortunate lacunae in our knowledge. Our chroniclers, on the whole blinkered by the linear trajectories of their narrow agendas — conversion, astronomy—lacked a vision that would have allowed them to explore broader connections. We can cite numerous examples that reveal all the idiosyncratic aspects into which they divided and disjointed the true annals of Amazonia. ${ }^{44}$

He goes on to describe several centuries of delirious description, from Crisotvao D'Acuna's River of Giants, to the dismissal of the Purus as a "waste of water." As da Cunha states, “"a waste of waters' ... repeating the lamentable exaggeration of old fantasies that branded those landscapes with a strange and mysterious luster ... among these errors, nothing is

\footnotetext{
${ }^{43} \mathrm{~A}$ varadouro is a footpath used by native Amazonians and backwoodsmen to connect watersheds. These could often be quite wide with considerable material moving from one watershed to the next.

${ }^{44}$ Da Cunha "Entre o Javari e a Madeira," O Paraíso Perdido, 15.
} 
revealed more than the propensity for the marvelous." ${ }^{45}$ He then reviews the works of chroniclers, church and military men, and scientists Who had plied this tributary since the seventeenth century. This was, of course, background research for his own voyage, but in contrast to other chroniclers, his narrative is animated with the turbulent history and migrations of tribes gone or diminished in his own time, and the floods of immigrants who replaced them. In his words:

The Muras, nomadic and wild and who so alarmed the colonial governments are not native - they descended from Bolivia via the Mamore and are perhaps relatives of the Moxos, who were successively embattled, first by the incursions of the Incas, and then other tribes from the South of our country who had been terrorized by the Paulistas. ${ }^{46}$ The Jamandis, residing deep in the forest and avoiding river margins, still retain the memory of the slave raids that expelled them from the Rio Negro. The Irurinas, in whom Silvio Coutinho glimpsed traces of the Ubaias of Paraguay; and the aspects and clothing of the Canamaris, vividly recall the stiff unsown "cushmas" (robes) of the Campas who live in the headwaters. These tribes swarmed both banks of the Purus. ${ }^{47}$

Da Cunha describes the Purus as a major channel of occupation and activity before the Brazilians arrived-"Remember that for centuries, the Purus was perhaps the major route through which continually passed the most remote tribes from the most distant parts of the continent," and then goes on to depict the social transformations of the area through the pressures of direct depredation on native groups, and the vast dislocations of Amazonian populations as Indians fled into forested redoubts. ${ }^{48}$ As indigenes declined by the mid 1800s, the demographic "void" of their passing was soon overrun by adventurers and explorers. These included notorious fortune hunters as the rubber baron Fitzcarraldo (Brian Sweeney Fitzgerald, later immortalized by Werner Herzog in the eponymous movie); members of the British Royal Society, such as Chandless; officers

\footnotetext{
${ }^{45}$ Da Cunha, "Geografia de Purus," O Paraíso Perdido, 141.

${ }^{46}$ The bandeirantes were the early explorers and slavers who moved from São Paulo up the tributaries to plunder and enslave natives and also to search for minerals; see Viana Moog, Bandeirantes e Pioneiros (Rio de Janeiro: Editora Globo, 1956); John Hemming, Amazon Frontier: The Defeat of the Brazilian Indians (Cambridge, MA: Harvard University Press, 1987).

${ }^{47} \mathrm{Da}$ Cunha, "O Povamento da Foz das Cabeceiras," O Paraíso Perdido, 158-9.

${ }^{48}$ Da Cunha, "O Povamento da Foz das Cabeceiras," O Paraíso Perdido, 156.
} 
of the U.S. Navy (Herndon, Maury); and characters such as Manuel Urbino, caboclo extraordinaire, who was the midwife to the informal colonialism, or what Riviere calls in the case of the annexation of British Guyana, "absent-minded imperialism" that gradually crept up the headwaters of the tributaries. ${ }^{49}$

As a mateiro, a kind of native environmental savant, anyone needing guides relied on Urbino, and he became a kind of genius loci of the occupation, guiding expeditions, contacting native populations, translating and helping to establish settlements. ${ }^{50} \mathrm{Da}$ Cunha goes on to describe the scores of migrants and the emergent towns such as Labrea. He documents the explosive colonization where, by 1873, Brazilians had arrived in Sobral, 1,400 kilometers up river from the mouth of the Purus. Colonization also came from the other direction, from Peru, but its mode of operation and its economic base, caucho rather than Hevea rubber, was often predicated on terrorized Indian labor and controlled in the end by the notorious Casa Arana, whose actions in Amazonia are so wrenchingly described by Taussig and Casement. ${ }^{51}$ As da Cunha notes, "In general there are Five Peruvians for 100 Piros, Campas, Amahuaca, Conibos, Sipibos, Cornuas, and Jaminuauas which one stumbles across in various types of usage and indolence, all conquered by the shotgun, all deluded by extravagant contracts, all now yoked to the most complete slavery." ${ }^{2}$

In his emphasis on the inhabited tropics, his works forged a theme that now infuses a great deal of contemporary scholarship focusing on the role that human populations have had on the structure of Amazonian environments. His attention to native populations was unusual for the time, since the practical response in the region was to either enslave, kill, or absorb indigenous groups. His dramatic descriptions of the

\footnotetext{
${ }^{49}$ Peter Riviere, Absent-Minded Imperialism (London: Tauris Academic Studies, 1995).

${ }^{50}$ Although a dying breed, mateiros are even today usually expert river pilots as well as highly informed about the habits and uses of the flora and fauna. Often married to natives or raised among them, these kinds of local natural historians instantiated the "transfer of technology" from native societies to caboclos, and also to visiting scientists.

${ }^{51}$ Toward the end of the rubber boom on the Amazon's upper tributaries, there were famous denunciations such as Roger Casement's indictment of the terror slavery of the Casa Arana. Of special importance was Roger Casement, "The Putumayo Indians," Contemporary Review 102 (1912): 317-28. His complete writings and the documents that led to the legal processes against the Casa Arana are to be found in Roger Casement's Heart of Darkness: The 1911 Documents. (Dublin: Irish Manuscripts Commission, 2003). Also see Michael Taussig, Shamanism, Colonialism and the Wild Man. A Study in Terror and Healing (Chicago: University of Chicago Press, 1987); Michael Stanfield, Red Rubber Bleeding Trees: Violence, Slavery and Empire in Northrwest Amazonia (Albuquerque: University of New Mexico Press, 1998).

${ }^{52}$ Da Cunha, "Povoamento da Foz das Cabeceiras" O Paraíso Perdido, 166.
} 
enslavement of tribes by caucheiros, or their obliteration by rubber tappers provides among the most disturbing images of the clash of cultures at the economic frontier. An Amazon teeming with natives, migrants, and history contradicted the impressions that dominated the understanding of Amazonia in the latter part of the twentieth century as a kind of trackless emptiness.

\section{Constructed Amazons: The Monstrous Races and Fabulous Places}

Da Cunha's writings on Amazonian nature are among the most luminous of all his texts, and the snippets here hardly do justice to his understanding of the natural world as social construct, organic process or metaphor. He was well educated in the biological and geological theories of the Amazon and the debates around its origins and dynamics. His materials on the natural history of the region reflect his palpable excitement about the Amazon that was in part stimulated by the complexity of the science then emerging about the region from both Europe and Portuguese analysts. ${ }^{53}$ He was perhaps one of Best Amazon scholars of his day, absorbing and assessing the works of centuries of scientists and chroniclers. Da Cunha had studied the great Brazilian naturalist Rodrigues Ferreira; the research of American explorers such as Fredrick Hartt, geologist and ethnographer from Cornell; and the writings of the more politically suspect Navy Lieutenants Maury and Herndon. No tropical explorer could ignore the geographer Alexander von Humboldt, or the great British naturalists Bates, Alfred Wallace, and Richard Spruce, and da Cunha was no exception. ${ }^{54}$ He especially admired the geographer Chandless, whose maps that da Cunha followed up the Purus, were, in a universe of lying cartographies, paragons of rigor.

He also had unlimited access to chronicles, bureaucratic documents, and the long literature of the imagined Amazon which no doubt pleased his literary heart. Certainly, what he understood better than most of the scientists and scientific tourists of the age was the impact of centuries of myth making, speculative maps, and individual preconceptions that

\footnotetext{
${ }^{53}$ See Arturo César Ferreira Reis, A Amazônia que os Portugeses Revelaram (Rio de Janeiro: Ministry of Education and Culture, 1956). Hecht 69

${ }^{54}$ See Alfred Wallace, Narrative of Travels on the Amazon and Rio Negro with an Account of the Native Tribes (London: Ward and Lock, 1853); Alexander von Humboldt, Personal Narrative of a Journey to the Equinoctal Regions of the New Continent (1814; reprint, London: Penguin, 1995); Bates, A Naturalist on the River Amazon; Spruce, Notes of a Botanist.
} 
formed a kind scrim through which people viewed "their" Amazon. Thus Alpine geomorphologist and creationist, Louis Agassiz, saw massive glaciation and Divine Creation producing the physical structure and biotic diversity of Amazonia. But other researchers promoted accurate theories that seemed equally as fantastic at the time, such as the tectonic rise of the Andes changing an ocean trench into the vast "Rio-Mar" or River-Sea of the Amazon. ${ }^{55}$ As he notes:

[T] he great river, notwithstanding its overriding monotony, evokes all manner of marvel, and equally inspires the innocent chronicler, the romantic adventurer, or the informed scholar. The Amazons of Orellana, the Curriqueres, the Giants, of Guillaume de Isle, and the Lake of El Dorado of Walter Raleigh all created out of our past such a dazzling and almost mythological cycle that these emanations still inhabit the most imaginative hypotheses of science .... In Amazônia it seems that the magnitude of the questions implies a certain unfettered discourse-inductions favor flights of fancy. Truths are hidden in hyperbole. In its inflated idealizations Amazonia is portrayed such that tangible elements of this surprising reality emerge in ways that the most quixotic dreamer can easily find himself in the company of the most exalted scholars. ${ }^{56}$

What he clearly saw was how science and history were triangulated on the axes of myth, partial observation, and predilection.

The "Scientific Amazon"

Da Cunha had thought about natural history a great deal, both in Os Sertôes and in his Amazon texts, and he viewed "nature" as one of the great actors in the human dramas that unfolded throughout Brazil. Like all geographies, his studies reflect both the abstracted nature, and the intermingling of man and nature. In his more theoretical approaches to nature, we can see his bias toward Darwinism and evolution, seeing landscapes of change rather than a static world. He sees transformation through the optics of catastrophism and gradualism. But in his social

\footnotetext{
${ }^{55}$ See Da Cunha, "Impressões Gerais" for discussion of the Frederico Harrt's and the Morgan Commission studies of Amazonian Geology. See also Charles Harrt, "Contributions to the Geology and Physical Geography of the Lower Amazonas," Bulletin of the Buffalo Society of Natural History (1874): 201-35.

${ }^{56}$ Da Cunha, "Impressões Gerais," Obra Completa, 251.
} 
geography, he is concerned with the more applied implications of the ideas of progress, social Darwinism, environmental determinism, and nineteenth-century theories of race-ideas that infused the colonial discourse on the tropics, and were especially important in mestizoized Brazil. These were urgent questions in the larger intellectual milieu of the time, but also reflected this especially tumultuous period in Brazilian history.

For da Cunha, however, Amazonia was mostly a young land, one that was forming itself through repeated dialectics of creation and destruction. In many senses, his understanding of nature fits better with that of Stephen Jay Gould's model of punctuated equilibrium than with many of his contemporaries. ${ }^{57}$ Thus, while he describes the landscape as one "fumbling for equilibrium," and as a catastrophic world built of gradual processes, his evocation of the river captures a dramatic dynamic:

The erratic turmoil of the river is revealed in its unending curves, hopelessly entangled, reminding one in its uncertain itinerary of a lost traveler, who, at fading horizons, returns to all its old paths, or propels itself into sudden short cuts .... At other points, it streams from unexpected side troughs into its own tributaries, thus becoming, illogically, a tributary of its own tributaries. It is always disordered, always insurgent, erratic, destroying, constructing-devastating in one hour what it built over decades - with the dread, the torment and the exasperation of monstrous, dissatisfied artist, retouching, redoing, and perpetually restarting an obscure painting. Such is the river, such is its historyInsurgent and incomplete. ${ }^{58}$

$\mathrm{Da}$ Cunha viewed the young landscape as evolving under his eyes, protean and unformed, hence the "last unfinished page of genesis, still writing itself." As he saw landscapes dissolve and evolve, so too ecosystems, societies and man under the onslaught of processes of natural catastrophe and creation.

\footnotetext{
${ }^{57}$ Stephen Jay Gould, The Structure of Evolutionary Theory (Cambridge, MA: Harvard University Press, 2003).

${ }^{58}$ Da Cunha, "Impressões Gerais," Obra Completa, 256.
} 
Nature and Society

Da Cunha's discussions of race in his opus Os Sertôes inspired an academic cottage industry in literary sociology that has continued for the better part of a century. ${ }^{59}$ What is clear in this novel is that he initially spouts the accepted urban dogmas of his day about the degeneracy of the mestizo and dark races, but by the end, he asserts, "I should have seen in those sturdy caboclos the hardy nucleus of our future, the bedrock of our race." ${ }^{60}$ This is his point of departure for his analysis of environmentalism and social Darwinism in Amazonia that stands in sharp contrast to his earlier positions. In an essay entitled "Clima Caluniado" (maligned climate), a masterpiece of wit and irony, he compares the careful "hygienic" colonial occupation carried out by the French and British with the tumultuous desperation of the Brazilian northeasterners. Tropical medicine and colonial administration were burgeoning fields at the time, stimulated by the emerging European empires, and colonial agencies developed a vast array of protocols ranging from civil construction to detailed prescriptions of suitable, salubrious activities and diets. ${ }^{61}$ This new colonist becomes a protégé of the state, which strictly regulates his life. What He points out is "What is chastening is not so much the prodigious labors of colonial medicine to adapt the colonizer to the environment, but rather the slow unraveling of the most tenacious efforts." ${ }^{\prime 2}$ He contrasted the colonial states' organized and managed migrations with the occupation of Acre:

The very antithesis of ordered and dignified migrations, these departures lacked the most mundane administrative supervision. The occupation of Acre is a historic case, entirely "accidental" and far removed from the orderly aegis of Brazil's "watchword" "Progress." Its origins were borne of Calamity-the periodic droughts of our Northeastern backlands that occasioned the exodus en mass of the flagellados [drought victims]. Here was no crisis of growth, or na excess of population flooding towards the frontiers, marching to fresh horizons, the embodiment of the triumphant March of the Races. Rather, it reflected dearth

\footnotetext{
${ }^{59}$ See for example, Adelino Brandão, Euclides da Cunha e a Questão Racial No Brasil: A Antropologia de Os Sertões (Rio de Janeiro: Presença, 1990).

${ }^{60} \mathrm{Da}$ Cunha, Os Sertões, 464.

${ }^{61}$ See for example David Arnold, The Problem of Nature: Environment, Culture and European Expansion (London, Blackwell, 1996).

${ }^{62}$ Da Cunha, "Clima Caluniado," Obra Completa, 275.
} 
and utter defeat by natural catastrophe. Its trajectory was one of stumbling, disordered flight. In the very inverse of natural selection - all the weak, the useless, the worn out, the sick, and the suffering, were sent off willy nilly to that wilderness.

When the great droughts of 1879-80 and 1889-90 blasted over the scorched backlands, the coastal cities of the littoral were soon flooded by a new population of terrifying starvelings, burning with Fevers and pox. The sole concern of the authorities was to free themselves as soon as possible of the invasion of moribund savages clogging the roads and waterways with the oppressive mien of the doomed. So, they sent them off to Amazonia - that vast empty unknown, to exile in their own country .... They left, famished, sick and febrile, thus liable to infect and corrupt the most salubrious place in the world. But once having carried out this purge, the government took no further interest. No government agent, no doctor accompanied the exiles whose sole and painful mission was to disappear. But they didn't disappear. On the contrary, in less than 30 years the state of Acre, which was nothing more than a vague geographic label, a swampy wilderness stretching interminably to the southwest, defined itself out of the blue, surging forward in economic stature .... And, in the mysterious extreme southwest of the Amazonas, where the remarkable William Chandless penetrated more than 3,200 miles without arriving at its limit, 100,000 frontiersmen, yes, a legion of 100,000 men, risen from the dead, sprang from nowhere, and reclaimed their national heritage in a novel and heroic way, extending the fatherland to the new territories that they occupied. ${ }^{63}$

Da Cunha goes on to recount the dramatic history of colonization, its trajectory inscribed in the shift in place names of the little estates from "Hell" to "Enchantment." In sharp contrast to racialist debates of the Day that viewed mixed bloods as "ugly, indolent, slothful and inert," ${ }^{64}$ or in the words of Russell Wallace who resumed the regional personality in this way-"lustful, drunken and thieving" and other commentators such as Agassiz who viewed Amazonia's only reasonable future as one based on white occupation, da Cunha describes thriving yeomen communities, with "well tended orchards and prudent husbandry." ${ }^{65} \mathrm{He}$ turns the racial

\footnotetext{
${ }^{63}$ Da Cunha, "Clima Caluniado," Obra Completa, 276.

${ }^{64}$ Dain Borges, "Puffy Ugly Slothful and Inert."

${ }^{65} \mathrm{Da}$ Cunha, "Brasileiros," Obra Completa, 307.
} 
environmental determinist discourse on its head by insisting that the climate exerted an "incorruptible supervision ... that eliminates the unfit by exile or death ... creating an abode for the strong, the enduring, and the good"- - his intrepid caboclos. ${ }^{66}$

\section{THE NATURE OF PRODUCTION:}

Hidden Social Histories and Comparative Development

Da Cunha's own collection of his Amazonian vignettes reconstructs the lost social history of the Amazon, and are contained in the volume $A t$ the Margins of History. Most of the essay fragments that comprise the first section, "Land without History," detail the forgotten forays into the region by clerics and adventurers. But his efforts concentrated on colonization of the upper reaches of the Purus River, and on the emergence of the new social formations associated with the extraction of latexes-one based on essentially corrupt and moribund elites, another founded by the brave guerilla fighters and stalwart caboclos who had taken on the task of creating a world and economy in the Amazon forests, and finally that of the caucho hunters. While the previous themes that I have discussed address the regional social histories implicitly, da Cunha was a careful observer who went to great lengths to detail what he saw. The iconography of the Amazon rubber economy is resolutely wedded to versions of debt peonage in Brazil and Bolivia, and terror slavery found on the Putumayo and elsewhere on the upper Amazon. But recent research suggests a much broader diversity of extractive forms was in place. ${ }^{67}$ The brutally enslaved debt peon, or native, reflects one reality, and one that was internationally publicized at the time through the efforts of explorer William Hardenburg, diplomat and Irish Nationalist Roger Casement, Alfred Rangel, and, of course, da Cunha himself. ${ }^{68}$ There is the desperate life of the tappers, residing in the "diabolical paradise of the rubber forests" where the tapper "Lavishly sustains the glutted and oppressive parasitism

\footnotetext{
${ }^{66}$ Da Cunha, "Clima Caluniada," Obra Completa, 281.

${ }^{67}$ Barbara Weinstein, Amazon Rubber Boom, 1850-1920 (Stanford: Stanford University Press, 1983); Stephen Nugent, “"Whither O Campesinato?' Historical Peasantries of the Brazilian Amazon," Journal of Peasant Studies 29:3 (2003): 152-89; Bradford Barnham and Oliver Coomes, Prosperity's Promise: The Amazon Rubber Boom and Distorted Development (Boulder: Westview Press, 1996); Hecht, "Fields, Forest and Families."

${ }^{68}$ Roger Casement's Heart of Darkness; Alfred Rangel, Inferno Verde: Scenas e Scenarios do Amazonas (Rio de Janeiro: Familiação, 1914); W.E. Hardenburg, The Putumayo: The Devil's Paradise (London: T. Fisher Unwin, 1912).
} 
that will never free him from the paths that enmesh him, and on which he will tread for the rest of his life, coming and going in the stultifying circuit of his monstrous and sterile routine." ${ }^{69}$ This reality comprised but one incarnation of rubber extraction. In any given region, the rubber economy was complex in its social forms. ${ }^{70}$

Da Cunha himself understood this, but as many of his writings remained in fragments and in official (rather than literary) reports, the varying forms he described seem to contradict each other, especially in light of the "blood rubber" version of latex extraction. He noted that although there were certainly seringais (estates) where peonage unfolded in unimaginably oppressive forms, there were also extractive systems in the western Amazon, at the height of the boom in the early 1900s where women and families were present in thriving yeomen communities. ${ }^{71} \mathrm{He}$ notes, as He ascends the Purus, the density of settlement, "the charm of that animated estate, with its rich agriculture, intelligently managed, with numerous habitations dotted along the river scarps." ${ }^{72}$ As he was traveling and writing to confirm the importance and permanence of Brazilian presence of the region to justify the new frontier boundaries of Peru and Brazil, He goes to pains to document the pace and density of Brazilian and Peruvian occupation and also notes the shift in the tone of the place names from the those of despair (Misericórdia) to cautious optimism (Vamos Ver-we'll see) to elation (Triumfo-triumph). For him, the key element of "order and progress" is the creation of small communities rather than large estates. His caboclos are proof of active and permanent colonization:

\begin{abstract}
Despite the haphazard and brutish manner of occupation and of life, the newborn society adapts and progresses. Its evolution, slow and continuous is apparent to even the least curious traveler in the Purus .... At first indifferent to the land, our pioneer settles in. Houses emerge in forest clearings, and on the river flats, and then on the solid bluffs above, one can see the first areas of farming. The gloomy barracks covered with palm branches are transmuted into regular homes or ample houses of rock and mortar. In Sebastopol, Canocory, São Luis de Cassauan, Itatuba,
\end{abstract}

\footnotetext{
${ }^{69}$ Da Cunha, "Entre os Seringais" O Paraíso Perdido, 215.

${ }^{70}$ Weinstein, Amazon Rubber Boom; Nugent, "Whither O Campesinato?"; Barnham and Coomes, Prosperity's Promise; Hecht, "Fields Forest and Families."

${ }^{71}$ See Wolff, Mulhers da Floresta; Hecht, "Forests Fields and Families."

${ }^{72}$ Da Cunha, "Brasileiros," Obra Completa, 307.
} 
Realizam and dozens of other settlements in the lower PurusIn Liberdade, Concordia, even in the most remote sites, their numerous houses cluster around the small churches, and expand into real villages. These are the material images of control and definitive possession, tangible evidence of social evolution. ${ }^{73}$

This tropical arcadia contrasts mightily with the social world and landscapes of the caucheiros. Da Cunha compares the sustainable extraction of the Hevea latex with that of caucho, which often requires cutting down the tree to collect its latex. The ecological extinction parallels that of the natives:

Thus they mastered this wild region. The caucheiros acted with feverish haste. They ransacked the surroundings, killing or enslaving in a radius of several leagues. In a few months, at the side of the initial hut (tambo) others multiplied, the little solitary shack transformed itself into an ample barracks or rough embarcadero- the houses became more dense-a mirage of progress at the edge of the wilderness, but one which would develop and decline in a decade. The caucheiros would stay only until the last caucho tree fell. They came, they ravaged and they left. ${ }^{74}$

He goes on to describe in moving passages the discovery his expedition makes at an abandoned caucho camp, which powerfully resumes the contempt that he felt for this nomadic form of occupation:

In one of the most maintained of the outbuildings, the last occupant awaited us. Piro, Amahuaca, or Campa, one couldn't distinguish the origin. The actual features of the human species were transmuted by the repulsive apparition — a deformed torso swollen by malaria seemed to take up his entire figure, in sharp contrast to the thin arms and bent and twisted legs like those of a monstrous fetus. He cringed in a corner and gazed at us impassively. At one side were all his belongings — a large bunch of green bananas.

This indefinable thing, which by a cruel analogy suggested by the circumstances, seemed less a man than a forgotten ball of caucho thrown in the corner by the extractors, answered our

\footnotetext{
${ }^{73}$ Da Cunha "Clima Caluniado," Obra Completa, 280.

${ }^{74} \mathrm{Da}$ Cunha, "Os Caucheiros," Obra Completa, 286.
} 
questions in a hoarse fading voice in a completely incomprehensible language. Finally, with enormous will, he lifted an arm, and extended it forward as though to indicate something he had been following for a long time, something beyond all those forests and rivers. He babbled, and letting his arm fall heavily as if he had lifted to a great height a heavy burden "amigos," he said: friends.

This: friends, companions, comrades of the busy days of harvests, who had left for other parts, abandoning him in absolute solitude.

Of the Spanish words he learned there remained only that, and the damned one murmured it with a touching gesture of longing. With poignant sarcasm, he unknowingly castigated those vile adventurers, who even then continued their routine devastation-opening new areas with carbine shots and slashes of machetes, regions that they would leave as they had left here. The final record of their tumultuous works would be scrawled in the crumbling shacks or written in the pathetic figure of the brutalized native; monuments to those builders of ruins. ${ }^{75}$

Da Cunha was deeply concerned about the social occupation and evolution of these nascent societies. Always attentive to social justice, he sees in the integration of the region and its caboclos an emerging and just future, in contrast to the mirage of development inherent in the Seringal and Caucho economies.

Da Cunha's observations on nature and society show a sensibility that resonates with modern political ecological concerns-but does that make him a political ecologist; and does it matter?

\section{FINAL THOUGHTS ON DA CUNHA AND "PROTO POLITICAL ECOLOGY"}

It is always a dangerous exercise to fit a highly original thinker from the past into the frameworks of today. There are three reasons why. First, it hobbles his concerns and ambitions to our categories, and this may be a mistake, because da Cunha's writing emerges from a quite different intellectual pedigree than that usually invoked for political ecology. Modern Marxist analysis of the political economy of development and

${ }^{75}$ Da Cunha, “Os Caucheiros," Obra Completa, 291-2. 
cultural ecology in anthropology and geography do not inform his efforts. There is virtually no reference to Marx in his correspondence or other writings, though it is unimaginable that da Cunha would have been unaware of him. Rather the modernizing visions of Auguste Comte (and the Comtean motto "order and progress"), the liberal democracy of both Benjamin Constants, the ideals of the French Revolution, and the nationalist aspirations of Rio Branco inspire his understanding as do the realities of Amazônia at the height of the rubber boom.

Second, while one could argue that he was a colonial agent for Brazil's territorial ambitions, he did not view the inhabitants or the Amazon itself as exotic, or his mission as a "civilizing one"-indeed, he finds the place in many ways boring and prosaic compared with other areas of the country. Rather he sees Amazonia and its peoples through the eyes of a sociologist seeking the validation of its local inhabitants, the creation of a national identity, new national foundation myths, and the consolidation of political space. The purposes of his work were pragmatic as well as literary-he was positioned in a unique way as hero of the revolution, artist, and bureaucrat to affect social change; it was always one of the goals of his writings. He was a modernizer and a populist.

Third, there is always the worry that today's label and sub-discipline becomes tomorrow's dated intellectual fad, perhaps exiling his singular contributions because of a "tagging" problem. ${ }^{76}$ But while his context and goals are very different, his concerns do presage themes of the politicalecological approach. First, da Cunha takes on "construction of nature" in ways often claimed by political ecology-the political economic implications of the ides of nature and analytical holism. His writings on racial theories and social Darwinism reflect important debates of the time, and relate more specifically to critiques of European colonialism.

Da Cunha approaches representation through mythologies and sciences in light of what this means about the region's history and future. In addition, he links these explicitly to political economies and Brazil's colonial ambitions in the region-an empty Amazon for him is one given over to the ravages of caucheiros and "unpleasant Peruvians"; one crammed with Brazilians and Indians is the precursor to a tropical Arcadia. His dynamic Amazon is a space of mythical, biological, and social evolution;

\footnotetext{
${ }^{76}$ Those who matured intellectually immersed in the dependency literature should take its fate as a cautionary tale.
} 
one of persistence, extinction and emergence; and one, he argues, that can only be understood in its complex totality. In spite of his predilection for rigorous scientific observation and positivist empiricism, he makes a plea for holism - the place cannot be understood by "stripping off its veils," but really only through seeing Amazonia as an integration of them all. Through it all, the question of social justice underpins his observations, and his central concern is not so much the ecological but the social outcomes of resource uses in the Amazon. This comparative analysis of differing social configurations in land use, and the logics and cultures that bolster them is a widely practiced analytic approach in contemporary political ecology.

But what else do analysts view as the hallmarks of political ecology? For Susan Paulsen, Lisa Gezon, and Michael Watts, one of the key analytical concepts is marginality. ${ }^{77}$ One segment of political ecology has aimed to show how central these "minor actors" have been in the creation of modern history. ${ }^{78}$ "Marginality" certainly is central to da Cunha's entire opus. His sertanejos, millenarians, Amazon caboclos, natives slipping away, are among the most marginal of the marginal, their barely discernible presence a wisp of smoke glimpsed at a distance. It is no accident that they inhabit his "Margins of History" and the spacious emptiness of the "Land without History." But da Cunha has a well-developed sense of irony, and his formidable ambition in his Amazonian writing is to wrest them from history's oubliette and thrust them into the vanguard and heart of the national project where in his view, they actually reside.

Another central theme in political ecology addresses the pressure on resources as it is mediated by social relations. His comparative studies of latex economies is an admirable review of environmental, social, and (for him terribly important) developmental consequences of differently structured forms of resource use. Like many involved in political ecology, his analysis underpins a policy position, and in this, his approach is completely modern.

If political ecology is an approach rather than a canon, then there is room for "proto political ecologists" like da Cunha, who can provide the analytic arena with a much broader pedigree and intellectual history. If

\footnotetext{
77 Susan Paulsen, Lisa Gezon, and Michael Watts, "Locating the Political in Political Ecology: Na Introduction" Human Organization 62:3 (2003): 105-16.

${ }^{78}$ See for example Judith Carney, Black Rice: The African Origins of Rice Cultivation in the Américas (Cambridge, MA: Harvard University Press, 2001). Also see Karl Offen's introductory essay in this volume of Historical Geography.
} 
the genealogy must be wed to particular late twentieth-century intellectual strains, then promising strands and inspirations may well be overlooked in favor of a kind of self-referential literature. It is equally dangerous to march political ecology precursors to the procrustean bed of its modern categories.

Da Cunha's works can probably be encompassed in today's political ecology, and his own efforts presaged many of its themes. However, this was hardly his purpose, and he defied narrow classifications in his own time. He wanted writing to have an effect on the world. His Amazon work shows his passionate political thought as he traveled through the region, observing its nature, describing its history, decrying its cruelty, lauding its caboclo conquerors, and imagining the Amazon with a just and equitable future.

\section{ACKNOWLEDGEMENTS}

The research for this paper was carried out under the auspices of fellowships from the American Council of Learned Societies and the Center for Advanced Studies in the Behavioral Sciences at Stanford University. Their support is gratefully acknowledged. I also thank the anonymous reviewers whose comments were very helpful in the final preparations of this manuscript. Special thanks also to the modern editorial saint, Karl Offen. 
